\title{
採骨を要しない頸椎前方（除圧）固定術
}

中瀬裕之朴永銖鄭倫成棉寿右

\section{Anterior Cervical Stabilization without the Harvesting of Autografts \\ by}
Hiroyuki Nakase, M.D., Young-Su Park, M.D., Rinsei Tei, M.D., and Toshisuke Sakaki, M.D. from

Department of Neurosurgery, Nara Medical University

\begin{abstract}
The purpose of this study was to evaluate the surgical results of anterior cervical stabilization using instrumentations alone without the harvesting of autologous bone grafts.

Since 2000, we have treated 72 patients (Male 46, Female 26, Age 39-79 years old) by anterior cervical stabilization without the harvesting of autologous bone grafts for cervical myelopathy and radiculopathy caused by spondylosis (36 cases), cervical disc hernia (25 cases), and OPLL (11 cases). Instrumentations used were a threaded cage for intervertebral disc degeneration and a titanium mesh cage with locking plate after corpectomy for muti-level disease of the cervical spine. The threaded cage was filled with hydroxyapatite and the mesh cage with autologous bone fragments taken from the removed vertebrae. The improvement rate by Neurosurgical Cervical Spine Scale (NCSS) was $67.9 \%$ (average) and stable bone union was obtained 6-12 months postoperatively. The average follow-up period was 17.4 months. Postoperative complications included dyspnea (2 cases), cerebrospinal fluid leakage treated by lumbar drainage (2 cases), swallowing disturbances (2 cases), neurological deterioration ( 1 case), and death by myocardial infarction ( 1 case). A mild sinking of the prosthesis was observed in 8 patients but did not require reoperation. There were no hardware complications.

This technique presents good clinical results and helps to avoid complications from the iliac crest donor site.
\end{abstract}

(Received February 5, 2003 ; accepted April 24, 2003)

Key words : cervical spine, anterior cervical fusion, autologous bone graft

Jpn J Neurosurg (Tokyo) $12: 670-675,2003$

\section{はじめに}

従来, 脊椎固定術には自家骨移植が用いられてきた。 しかし自家骨採取には, 採骨部の疼痛・感染, 血腫, 神 経障害，骨折などの合併症が知られている7)22)。近年, 数々の手術法が工夫され, major complication は回避でき るようになってきたが, 知覚障害や創部の醜状などの minor complication は, 依然 $30 \%$ 以上に合併する1). 特に 自家骨採骨部の疼痛は頻度が高く, $2.8 \sim 49 \%$ と報告され ている6)7)12)14)20) 〜22).
われわれは 1997 年以降, 頸椎前方固定術において, instrumentationを積極的に採用してきた. instrumentationを用いた頸椎前方固定術においても, 当初, interbody cage 内には，あくまで腸骨棱から海綿骨を採取し， 充填してきたが9)，2000 年後半よりは椎体削除の際の骨 屑に人工骨 (hydroxyapatite) を追加することで，採骨し ない方法を行っている. また, 頸椎変性疾患に対して椎 間からの手術だけでは十分な除圧が得られない場合や 3 椎間以上の場合は, 椎体削除を行い, titanium mesh cageの中に削除した骨片を充填することにより，自家骨

奈良県立医科大学脳神経外科 $/ \bar{T} 634-8522$ 楅原市四条町 840 〔連絡先：中瀬裕之〕

Address reprint requests to: Hiroyuki Nakase, M.D., Department of Neurosurgery, Nara Medical University, 840 Shijo-cho, Kashihara-shi, Nara 634-8522, Japan 


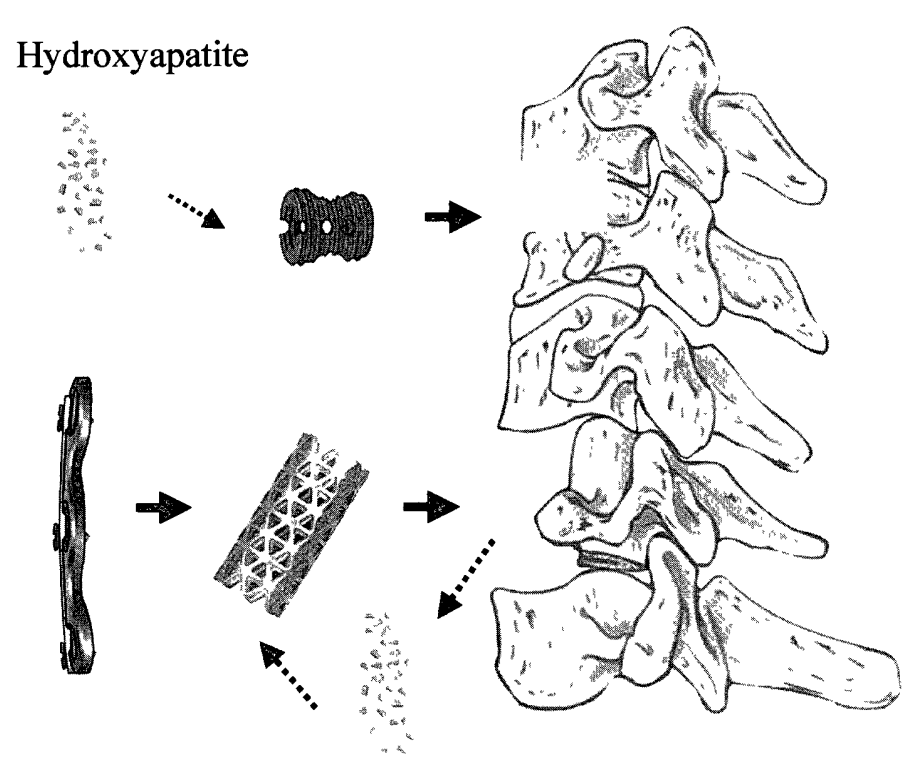

Autologous bone fragment

from the removed vertebrae

Fig. 1 Schema of anterior cervical stabilization using just instrumentation without harvesting any autologous bone grafts

The threaded cage was filled with hydroxyapatite and the mesh cage with autologous bone fragments taken from the removed vertebrae.

採取を行っていない ${ }^{17)}$. 本稿では，自家骨採取をせずに 行った頸椎前方固定術の術後成績について報告する。

\section{対象と方法}

症例は, 男性 46 例，女性 26 例（年齢 $39 \sim 79$ 歳）の 計 72 例である. 診断は変形性頸椎症（頸椎管狭窄症を 含める） 36 例，椎間板ヘルニア 25 例，後縦勒帯骨化症 （OPLL）11 例で, 全例で頸髄症もしくは強い痛みを伴う 神経根症状を認めた. 72 例のうち椎体削除を行った症例 が 14 例あり, 削除椎体は 7 例で 1 椎体, 6 例で 2 椎体, 1 例で 3 椎体であった. 72 例から椎体削除した 14 例を 省いた 58 例中, 手術した椎間は, C $3 / 4$ が 6 例, C $4 / 5$ が 14 例，C5/6 が 34 例，C6/7 が 16 例であった。使用 した instrumentationは，椎間固定には cage（Novus CT, Kobayashi Sofamor Danek, Osaka) を，椎体削除後の前方 固定には titanium mesh cage (PYRAMESH, Kobayashi Sofamor Danek, Osaka) $と$ locking plate (ATLANTIS, ZEPHIR, Kobayashi Sofamor Danek, Osaka）を使用した. cage の中には, fibrine glue を混ぜた粉状の hydroxyapatite を充填し, titanium mesh cage には削除した椎体を充 填し，いずれも自家骨採取は行わなかった（Fig. 1)。神 経症状は, 脊椎・春葡疾患の神経症状判定基準（Neurosurgical Cervical Spine Scale ; NCSS) ${ }^{10)}$ で評価した。骨癒

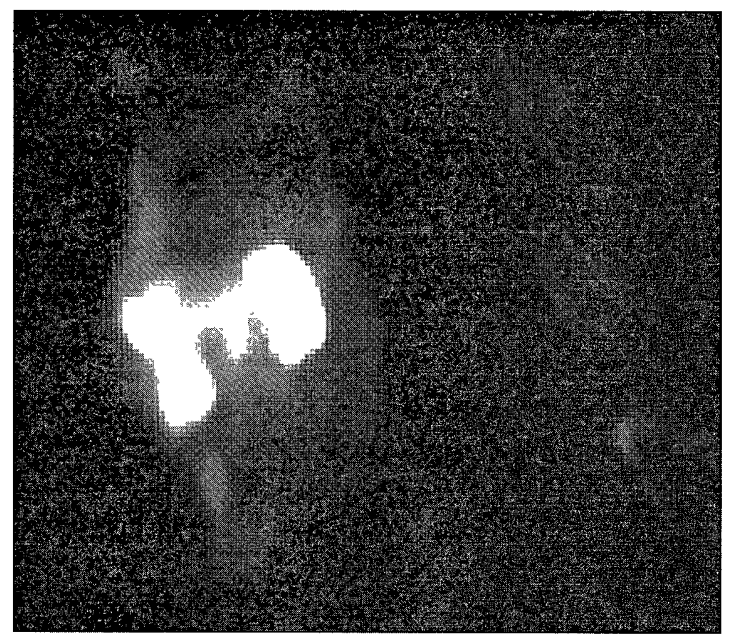

Fig. 2 Three-demensional computed tomogram indicates successful interbody spine fusion between bone the inside and around the cage and live bone.

合は, 術後 $3 ， 6 ， 12$ 力月後の 3D-CT (矢状断像) で評 価した（Fig. 2)。隣接椎間の変化は MRI で検査した。

\section{手術法}

全身麻酔下に患者の頸部左側より侵入する，皮膚切開 は 2 椎間まで, もしくは削除する椎体が 1 椎体の場合は 


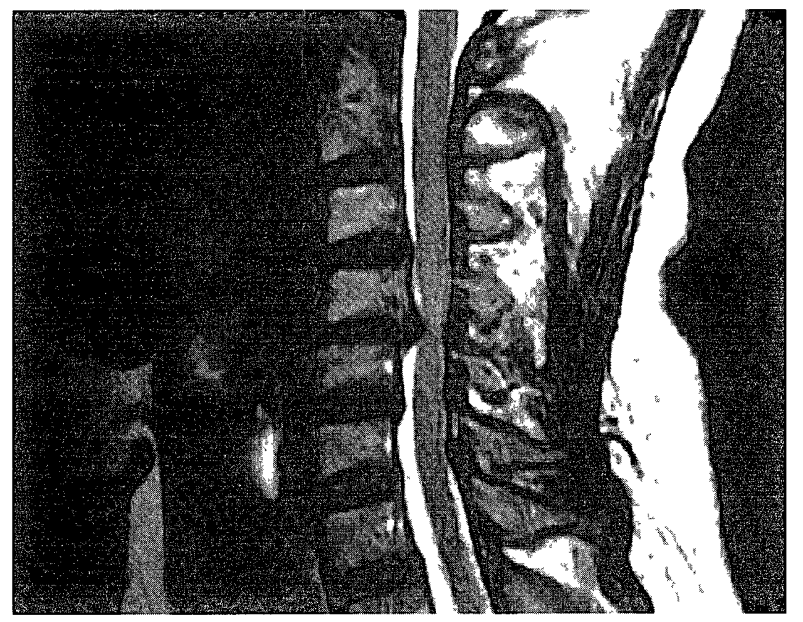

Fig. 3 T2-weighted sagittal view of magnetic resonance image reveals compression of the spinal cord by disc hernia at $\mathrm{C} 4 / 5$ level.

前頸部横切開を，3 椎間以上や 2 椎体以上の削除を行う 場合は，2 本の前頸部横切開もしくは胸鎖乳突筋前縁に 沿つた縦切開を行った．頸椎前方アプローチにて椎体前 面に達した後, 椎間の軟部組織や骨棘を削除し, 十分に 脊髄および神経根が除圧できたら，Novus CT に fibrine glueを混ぜた粉状の人工骨（hydroxyapatite）を充填し, cage を挿入し椎間固定を行った. sinking を予防するため に, subcondral bone をできるだけ温存し，通常は 1 椎間 に 2 個の cage (double cage) で固定している.

椎体削除の場合は，切除予定の椎体を露出したら rongeurで椎体を削除し，これを集めておき，後で titanium mesh cage に充填した. mesh の長さを調整後, distraction screw（TrimLine, Kobayashi Sofamor Danek, Osaka) で上 下の椎体に軽度 distraction をかけて, 粉砕した椎体骨を 充填した mesh を固定し，その後， locking plate を設置 した (Fig. 1)。いずれの場合も，術中透視で cage もしく は mesh と plate の位置を最終確認した。

術当日からフィラデルフィアカラーを装着し, 術翌日 から座位，トイレ歩行を許可した， $3 \sim 7$ 日後にソフトカ ラーに変更し, 平均 2 週間でカラー装着を終了した。

\section{結 果}

術後 7〜29 力月 (平均 17.4 力月) の経過観察を行い, 術 前の NCSS は 6 11 点（平均 9.4 点）で, 術後最も改善 した時点での NCSS は 10〜14 点（平均 12.1点）であっ た。平均改善率は $67.9 \%$ あったた。

合併症としては，心筇梗塞による死亡が 1 例，呼吸障 害 2 例（再挿管 1 例, 気管切開 1 例), 䯆液漏 2 例, 軽

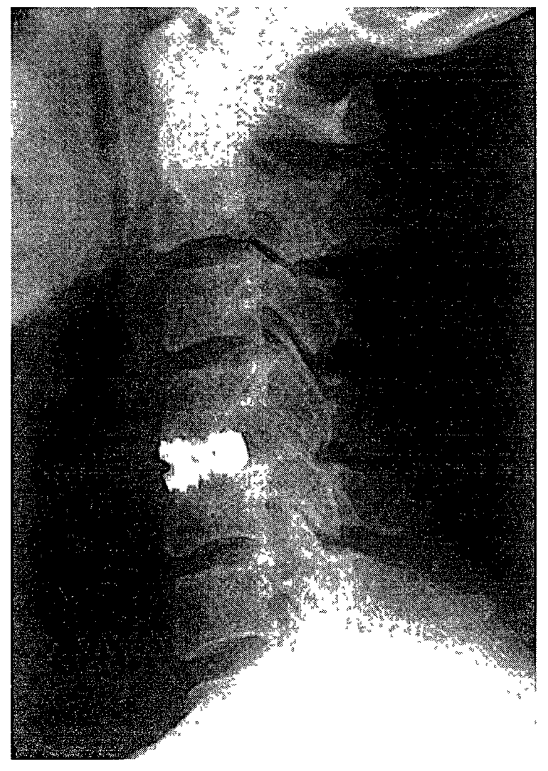

Fig. 4 Postoperative neuroimage Lateral $\mathrm{X}$-ray demonstrates anterior cervical fusion with double threaded cages.

度嬩下障害 2 例 ( 1 例で術後 16 力月後に骨癒合を確認し た後に plate を抜去した), 神経症状の悪化（神経根症） 1 例であった。軽度の sinking は 8 例でみられたが, 再 手術を要したものはなかった. 術後感染, instrumentation failure は認めなかった。 骨癒合は, 術後 6〜12 力月後で 良好であることが確認された，追跡期間中，隣接椎間の 変化はみられなかった。

\section{症例呈示}

\section{【症例 1】}

患 者: 67 歳, 女性.

現病歴：1 年前に左上肢のしびれを自覚し, 近医受診し た。変形性頸椎症と診断され, 薬剤および頸部牽引によ り症状は改善した. 2 力月前から再び症状が再燃し, 再 度同様の治療を受けるも改善せず, 背部痛および歩行障 害が出現してきたため, 当科に紹介された。

初診時神経学的所見: 四肢感覚障害 (特に上肢), 左握 力低下, 左下肢筋力低下, 歩行障害, 両下肢腱反射光進, 病的反射を認めた（NCSS $3: 3: 3)$.

画像所見: 頸椎単純写および MRI では, C4/5 での軽度 不安定症, および $\mathrm{C} 4 / 5$ に椎間板へルニアによる脊髄圧 迫を認めた（Fig. 3).

手 術: 左前頸部横切開を行い, 前方到達法により手 術顕微鏡下に $\mathrm{C} 4 / 5$ の椎間板ヘルニアを削除し, 春䯣お よび神経根を除圧した。硬膜上から脊髄の良好な拍動が 


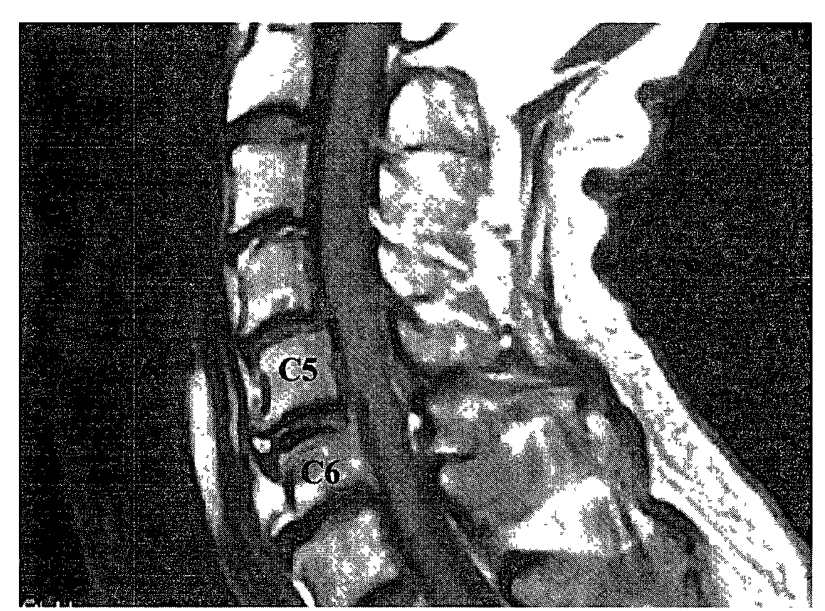

Fig. 5 T1-weighted sagittal view of a magnetic resonance image shows compression of the spinal cord at $\mathrm{C} 5-\mathrm{C} 6$ level (Reproduced from reference $^{18)}$ ).

確認された。次いで, $6 \mathrm{~mm} の$ Novus CT に fibrine glue を混ぜた粉状の hydroxyapatite を充填し， 2 個の cage を 挿入し椎間固定を行った（Fig. 4).

術 後: 術翌日からフィラデルフィアカラーを装着し た状態で, 座位, トイレ歩行を許可した. 3 日後にソフ トカラーに変更し, 2 週間でカラー装着を終了した。両 指先のしびれを残し, 術後 16 日目に退院した。退院時の

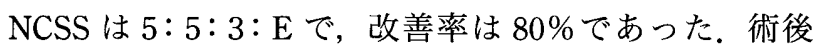
4 力月目の外来診察時には, NCSS は 5:5:4:E となっ た. 術後 6 力月後の 3D-CT スキャンの矢状断像では, 良好な骨瘉合が確認された。

\section{【症例 2】}

患 者: 75 歳, 男性.

現病歴：1力月前から四肢のしびれおよび歩行障害を 自覚し, 近医を受診した. 頸椎症性頸髄症の診断で当科 に紹介された ${ }^{18)}$.

初診時神経学的所見: 握力低下, 下肢腱反射元進, 四肢 感覚障害, 歩行障害を認めた（NCSS $2: 3: 2)$.

既往歴: 前立腺癌の手術, 肝機能障害.

画像所見：頸椎単純写および MRI では, 頸椎症と C5/ 6 での不安定症, および C $4 / 5$ から C $6 / 7$ にわたる春髄圧 迫を認めた（Fig. 5). 術前および術後管理について, 泌 尿器科および内科と十分協議したうえで手術を行った。

手 術：前方到達法により C5, C6 の椎体削除を行い, 脊髄および神経根の十分な除圧を行った後に, $37.5 \mathrm{~mm}$ にトリミングした titanium mesh cage $(14 \times 10 \mathrm{~mm})$ に粉 砕した椎体骨を充填し，これを挿入し固定した ${ }^{4) 12)}$. 60 $\mathrm{mm}$ の locking plate を設置し, 術中透視で cage と plate

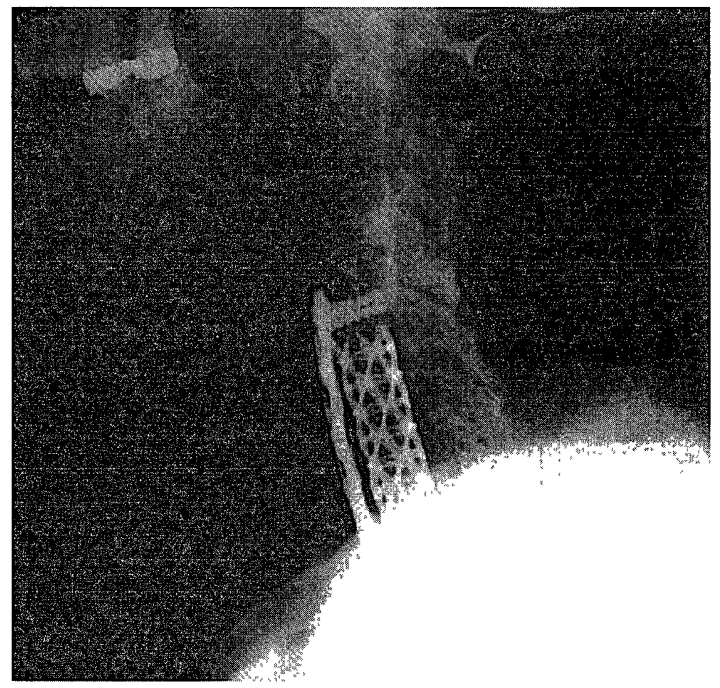

Fig. 6 Postoperative neuroimage

Lateral X-ray demonstrates anterior fusion with mesh cage and plate at $\mathrm{C} 4-\mathrm{C} 7$ (Reproduced from reference $\left.{ }^{18)}\right)$.

の位置を確認し手術を終了した（Fig. 6)。術中に施行し た運動誘発電位に, 変化は認められなかった。

術 後: 術後経過は良好で, 退院時には四肢のしびれ, 歩行障害は改善した。退院時の NCSS は 4:4:3: E で, 改善率は $57 \%$ であった. 6 力月後の $3 \mathrm{D}-\mathrm{CT}$ スキャンの 矢状断像では, 良好な骨癒合が確認された。術後 1 年半 の現在, 神経学的に異常なく, 隣接椎間の変化は認めて いない.

\section{考 察}

自己骨移植は骨癒合に優れ，脊椎固定術に最も一般的 に用いられている27). しかし，自家骨採骨に伴う合併症 や採取できる骨の量や形状に制限があること, 高齢者や 骨粗鬆症など骨の脆弱性のある症例では採取骨の強度が 問題となる．そのため，人工骨や各種のスペーサーが用 いられるようになってきている12)16)19).

本邦では 1997 年より頸椎椎間固定用 cage（threaded titanium cage）が世界に先駆けて導入されている8)12)13). cage 表面の thread により良好な初期固定性があるため, 術後の安静期間や入院期間の短縮に役立っている ${ }^{16)}$.

われわれの施設では, 当初, 骨癒合の観点から cage 内 には髄質骨を充填していたが9)，2000 年からは椎体削除 の際の骨に，人工骨 (hydroxyapatite) を追加することで 採骨しない方法を行っている。この方法でも感染や cage の逸脱による再手術例および抜去例はなく，良好な成績 が得られている，6〜12 力月後には， cageを核とした 
remodeling の完成が確認されている。十分な骨癒合を得 るには, Cunningham ら ${ }^{4)}$ の報告が示すように, cage を自 家骨で充填する方が有利であるが，われわれのように， 骨採取の問題をなくすために自己骨を充填しない施設も 増えてきている。

術後の採骨部疼痛は, 早期離床の妨げとなる。疼痛発 生頻度は，2.8４9\% と報告により差がみられ(67)12214) 20) 22)，これは分析法の違いによるものと考元られてい る. Heary $ら^{7)}$ の報告によると, 術後に外科医自らが患 者に質問した疼痛の頻度 $(8 \%)$ と, 健康管理師が電話 で行ったインタビュー（34\%）とでは, 明らかに疼痛発 生頻度が異なっていた。

また一方で, 採骨部疼痛は精神的な要素が混在してい るとする報告もある．Fernyhough らは5)，採骨部疼痛は， 脊椎変性疾患術後 $(26 \%)$ では脊椎外傷後 $(13 \%)$ より も2 倍発生率が高いことを指摘し, Summers ら ${ }^{22)}$ は脊椎 手術の結果に満足している患者 $(42 \%)$ よりも不満足な 患者 $(69 \%)$ の方が, 疼痛発生頻度が有意に高いことを 報告している。このように，採骨部疼痛は多様な因子が 関係しており，一概に論じることはできないが，われわ れ外科医が考えているょりも, 患者の術後に悪影響を与 えていることは確かなようである。

しかし一方で, 腸骨移植は Smith-Robinson 以来約 50 年の症例の集積があり, 良好な成績が多数報告されてい る.したがって，すべての症例で mesh cage を含めた instrumentation が適応になるかどうかは，今後の課題で ある。

病巣が多椎間レベルに及ぶ頸骮有症 (myelopathy) の症 例に対する前方到達法の際3)1115), われわれは従来, 椎 体切除後に腸骨を移植した椎体固定を行ってきた。しか し時に大きな移植骨を必要とし, 採骨に関する問題があ るため, 1999 年 9 月より自家腸骨に代えて titanium mesh cage と locking plate を用いた固定法を行っている. 本法を用いて治療し, 術後 1 年以上経過した 16 例につ いての術後成績については，すでに報告している ${ }^{17)}$ 。こ の 16 例の中には, 転移性頸椎腫䀛 3 例と感染性頸椎炎 2 例が含まれており，このような場合は削除椎体は使え ないので, mesh cage 内に腸骨からの自家骨を充填して いる. 本研究では, 自家骨採取を行う必要のない変性疾 患のみを対象とした。 本法で mesh cage を用いることに より，どのような大きさの欠損にも術中にトリミングす ることで対応でき, 採骨の問題がない，そのぶん，手術 時間も短縮できるものと思われる.

頸椎症, 頸椎椎間板ヘルニア, OPLL などの頸椎変性 疾患は高齢者に多く, instrumentation を有効に利用する
ことにより，自家骨採取に伴う合併症の回避，手術時間 の短縮が可能となり,さらには早期離床によりリハビリ テーションを積極的に行える場合がある ${ }^{18)}$. 高齢者では 長期臥床を避けることは重要である，また多忙な現代人 の生活を考えると, 早期離床および早期社会復帰を考慮 した治療計画を立てる必要がある。

\section{結 論}

自家骨採取をせずに行った頸椎前方固定術は，骨採取 に伴う合併症を回避し，早期離床，早期社会復帰を可能 にするのに有効である.

\section{文 献}

1) Banwart JC, Asher MA, Hassanein RS: Iliac crest bone graft harvest donor site morbidity: A statistical evaluation. Spine 20: 1055-1060, 1995.

2) Bishop RC, Moore KA, Hadley $\mathrm{MN}$ : Anterior cervical interbody fusion using autogeneic and allogeneic bone graft substrate: A prospective comparative analysis. J Neurosurg 85: 206-210, 1996.

3) Cooper PR: Anterior cervical vertebrectomy: Tips and traps. Neurosurgery 49:1129-1132, 2001.

4) Cunningham BW, Kanayama M, Parker LM, Weis JC, Septer JC, Fedder IL, McAfee PC: Osteogenic protein versus autologous interbody arthrodesis in the sheep thoracic spine: A comparative endoscopic study using the Bagby and Kuslich interbody fusion device. Spine 24:509-518, 1999.

5) Fernyhough JC, Schimandle JJ, Weigel MC, Edwards CC, Levine AM. : Chronic donor site pain complicating bone graft harvesting from the posterior iliac crest for spinal fusion. Spine 17: 1474-1480, 1992.

6) Goulet JA, Senunas LE, DeSilva GL, Greenfield ML: Autogenous iliac crest bone graft: Complications and functional assessment. Clin Orthop 339: 76-81, 1997.

7) Heary RF, Schlenk RP, Sacchieri TA, Barone D, Brotea C: Persistent iliac crest donor site pain: Independent outcome assessment. Neurosurgery $\mathbf{5 0}: 510-517,2002$.

8）飛騨一利, 岩崎喜信, 阿部弘：頸部脊椎症に対するチ タン製ケージ 1 年以上使用の経過観察. 脊椎脊骾 13 : 47-50, 2000.

9）井田裕己, 森本哲也, 中瀬裕之, 榊 寿右：種々の instrumentation を使用した頚椎前方固定術一自家骨移植との 比較。脊髄外科 15: 105-110, 2001 .

10）角家 暁：日本脊髄外科研究会 脊椎・脊䯣疾患の神経 症状判定基準について。春髄外科 $6: 3-5,1992$.

11) Kinoshita A, Kataoka K, Taneda $M$ : Multilevel vertebral body replacement with a titanium mesh spaser for aneurysmal bone cyst: Technical note. Minim Invas Neurosurg 42: 156-158, 1999.

12）久保和親，中川 裕，陰山博人：Instrumentation surgery 2. 頸椎病変. 花北順哉, 山浦 晶, 戸山芳昭編: 春椎 - 春 髄外科の最前線. 東京, 先端医療技術研究所, 2002, pp.8287.

13）久保和親, 中川 裕, 黒木 実, 亀井裕介, 辻有紀子, 滝 和郎: Cervical interbody cage fixation. 脊椎脊髄 13 : 
$39-45,2000$.

14) Kurz LT, Garfin SR, Booth RE Jr: Harvesting autogenous iliac bone grafts: A review of complications and techniques. Spine 14:1324-1331, 1989.

15) Mayr MT, Subach BR, Comey CH, Rodts GE, Haid RW Jr : Cervical spinal stenosis: Outcome after anterior corpectomy, allograft reconstruction, and instrumentation. $\mathrm{J} \mathrm{Neu}$ rosurg 96 (Spine 1) : 10-16, 2002.

16) McAfee $\mathrm{PC}$ : Interbody fusion cages in reconstructive operations on the spine. J Bone Joint Surg Am 81:859$880,1999$.

17）中瀬裕之，井田裕己，鄭 倫成，榊 寿右，森本哲也： 多椎間症例に対する頝椎前方到達法一Titanium mesh cage と locking plate を用いた頝椎前方固定術。春髄外科 16:105-112, 2002.

18）中瀨裕之，鄭 倫成，朴 永銖，榊 寿右，森本哲也： 高齢者に対する春椎手術一手術適応と問題点．脊䯣外科
17:23-28, 2003.

19）西村文彦，二階堂雄次，山田與徳，朴 永銖，横田 浩, 栗岡久暢：Hydroxyapatite を応用した頝椎前方固定術一 Cloward, Smith-Robinson, strut type を 3 種類 の graft を用いて，春髅外科 $15 ： 15-22 ， 2001$.

20) Sawin PD, Traynelis VC, Menezes AH: A comparative analysis of fusion rates and donor-site morbidity for autogeneic rib and iliac crest bone grafts in posterior cervical fusions. J Neurosurg $\mathbf{8 8}: 255^{-265}, 1998$.

21) Schnee CL, Freese A, Weil RJ, Marcotte PJ: Analysis of harvest morbidity and radiographic outcome using autograft for anterior cervical fusion. Spine 22:2222-2227, 1997.

22) Summers BN, Eisenstein SM: Donor site pain from the ilium: A complication of lumbar spine fusion. $J$ Bone Joint Surg $\mathrm{Br}$ 71:677-680, 1989 .

採骨を要しない頸椎前方（除圧）固定術

\section{中瀬 裕之 朴永銖 鄭 倫成 榊 寿右}

自家骨採取をせずに行った頸椎前方（除圧）固定術の術後成績について報告した，症例は，男性 46 例, 女性 26 例（年齢 39〜79 歳）の計 72 例で, 変形性頸椎症（頸椎管狭窄症を含める） 36 例, 椎 間板ヘルニア 25 例, 後縦靶帯骨化症 (OPLL) 11 例である. 椎間固定には threaded titanium cage を, 椎体削除後の前方固定には titanium mesh cage と locking plate を使用した. cage の中には, fibrine glue を混ぜた粉状の hydroxyapatite を充媜し， titanium mesh cage には削除した椎体を充媜 し，いずれも自家骨採取は行わなかった.

術後 7〜29 カ月（平均 17.4 力月）の経過観察を行い, 術前の NCSS は 6〜11点（平均 9.4 点） で, 術後, 最も改善した時点での NCSS は 10〜 14 点 (平均 12.1 点) であった. 平均改善率は $67.9 \%$ であった. 術後感染や instrumentaticn failure は認められなかつた.

自家骨採取をせずに行った頸椎前方固定術は，骨採取に伴う合併症を回避し，早期離床，早期社会 復帰を可能にするのに有効である.

脳外誌 $12: 670-675,2003$ 